\title{
Fleshy Polypoidal Painless Subungual Mass of the Thumb
}

\author{
Piyush Kumar $^{a}$ Anup Kumar Tiwary ${ }^{b}$ Rizwana Barkat ${ }^{a} \quad$ Ghuncha Alam $^{a}$ \\ ${ }^{a}$ Department of Dermatology, Katihar Medical College and Hospital, Katihar, India; ${ }^{\mathrm{b}}$ Department of Dermatology, \\ Government Medical College, Haldwani, India
}

\section{Question}

A 52-year-old man presented with a slow growing, asymptomatic mass under the nail plate of the right thumb for the past 20 years. On examination, it was soft to firm in consistency, arising from the medial half of the nail bed. The overlying nail plate was onychogryphotic with splitting in the middle. The medial half of the nail plate was lifted off the underlying nail bed (Fig. 1). No other nails were affected with a similar or different condition, and the rest of the mucocutaneous examination was noncontributory. Radiographic images of the digit showed soft tissue tumor with no bony changes.

What Is Your Diagnosis?

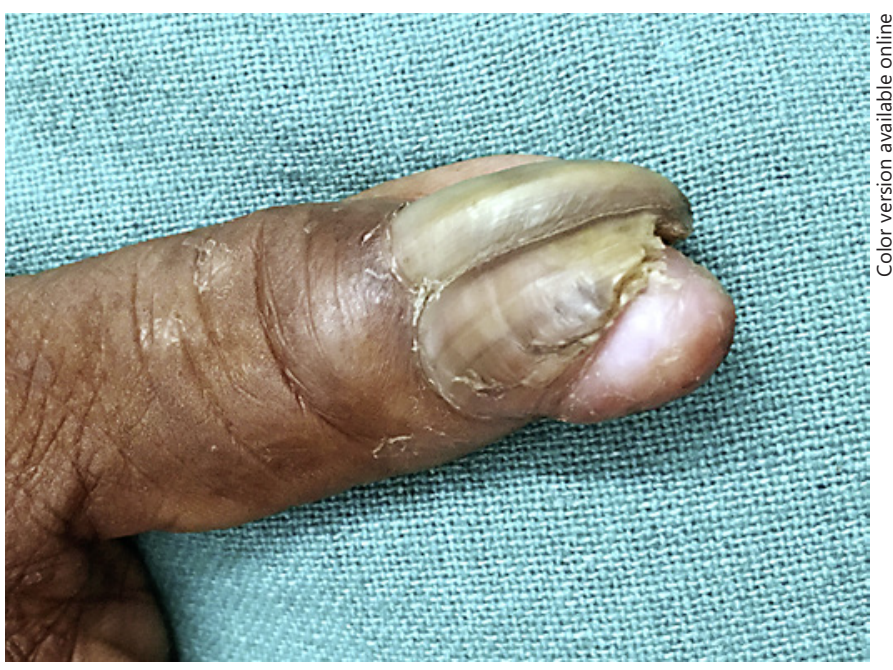

Fig. 1. Flesh-colored soft to firm growth arising from the medial half of the subungual area of the right thumb, causing split nail plate deformity. 


\section{Answer}

\section{Superficial Acral Fibromyxoma}

The medial half of the nail plate was removed under the ring block of the thumb, and the tumor was visualized as a $1.5-2 \mathrm{~cm}$ mass without any overlying skin changes. The tumor was carefully excised and sent for histopathology. It showed a dermal tumor composed of bland spindle and stellate cells within a myxoid stroma. The spindle cells were arranged in random, storiform, and fascicular growth patterns (Fig. 2). The dermis was notable for abundant deposition of mucin, and collagen was scant in these areas of mucin deposition. The overlying epidermis appeared stretched and showed orthohyperkeratosis. All these histopathological findings were consistent with the diagnosis of superficial acral fibromyxoma.

\section{Discussion}

Superficial acral or digital fibromyxoma is a rare, benign, slow growing myxoid tumor which commonly involves the periungual and subungual regions of the hands and feet. It usually presents as a painless, solitary, fleshcolored/pinkish, dome-shaped or polypoidal firm mass of $0.5-5.0 \mathrm{~cm}$ in size. Other sites are the ventral aspect of fingers, palm, ankle, and heel [1]. These are twice as common in males than in women and the mean age is 46 years [2]. Nails may get involved in up to $50 \%$ of cases and bony involvement may also be seen in more than one-third of cases [3].

Histopathology reveals a lobular nonencapsulated tumor of the dermis with no epidermal connection, which may extend into the subcutaneous tissue, underlying fascia, or periosteum. The tumor has lobular morphology with irregular and infiltrative margin, comprising of stellate and spindle-shaped fibroblast-like cells arranged in a loose storiform or fascicular growth pattern [2]. Depending upon the duration of the tumor, the surrounding stroma may be myxoid, myxocollagenous, or predominantly collagenous [4]. The presence of mast cells with few multinucleated cells and increased vascular proliferation within stroma are other characteristic features [5]. The tumor cells are diffusely immunoreactive for CD34, CD99, and focally for epithelial membrane antigen $[1,6]$.

The differential diagnosis includes acquired digital fibrokeratoma, Koenen's tumor, acral myxoinflammatory fibroblastic sarcoma, myxoid neurofibroma, and derma-

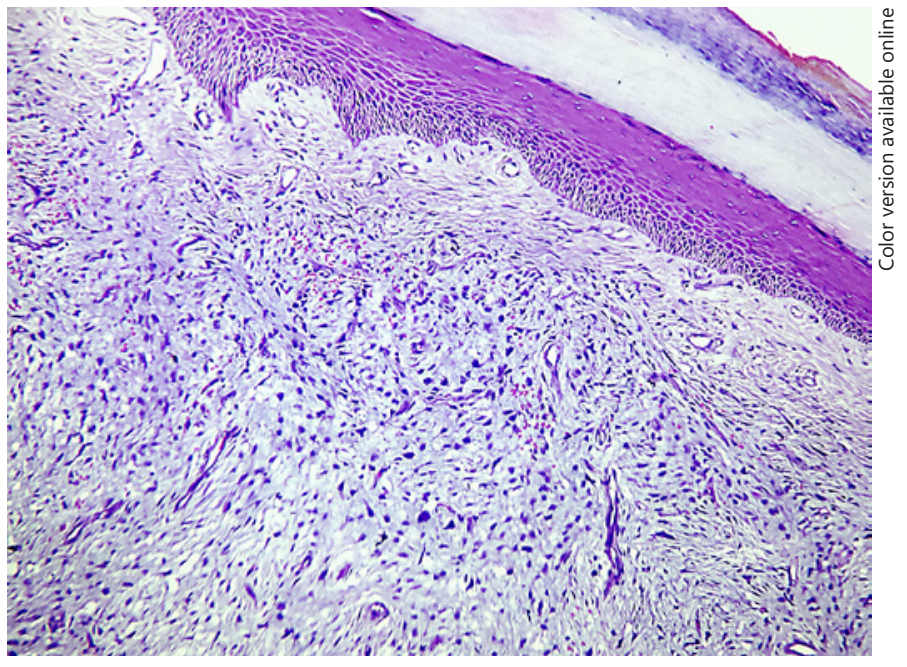

Fig. 2. The spindle cells are arranged in a random, loose storiform pattern in a myxoid stroma with scant collagen. Overlying epidermis is stretched and shows orthohyperkeratosis $(\mathrm{H} \& \mathrm{E}, \times 100)$.

tofibroma. Digital myxoid pseudocyst and distal digital subungual keratoacanthoma may also mimic the clinical picture of SAFM but with distinct histopathology. The cutaneous and histopathologic features of these diseases are summarized in a table (Table 1) [2, 5, 7-9].

The treatment of choice of SAFM is complete surgical excision with up to $25 \%$ chance of local recurrence in cases with initial positive margins [10].

\section{Statement of Ethics}

The patient has given her informed consent.

\section{Disclosure Statement}

The authors have no conflicts of interest to declare. There were no funding sources for this work.

\section{Keywords}

Fibromyxoma · Myxoid · Digital 
Table 1. Differential diagnoses of superficial acral fibromyxoma

\begin{tabular}{|c|c|c|}
\hline Differential diagnosis & Cutaneous features & Histopathologic features \\
\hline $\begin{array}{l}\text { Digital mucous/ } \\
\text { myxoid pseudocyst }\end{array}$ & $\begin{array}{l}\text { Solitary, painless, soft to firm, smooth, cystic } \\
\text { nodule } \\
\text { Present on or proximal to proximal nail fold, or } \\
\text { beneath the nail matrix }\end{array}$ & $\begin{array}{l}\text { Multilocular cysts with no epithelial lining, surround- } \\
\text { ed by ill-defined fibrous stroma and sub-epidermal } \\
\text { mucin deposition }\end{array}$ \\
\hline $\begin{array}{l}\text { Acquired digital } \\
\text { fibrokeratoma }\end{array}$ & $\begin{array}{l}\text { Solitary, firm, elongated periungual outgrowth } \\
\text { with narrow base and a collarette of slightly } \\
\text { raised skin }\end{array}$ & $\begin{array}{l}\text { Hyperkeratosis, acanthosis, perivascular fibrosis, } \\
\text { vertically oriented dense collagen bundles }\end{array}$ \\
\hline $\begin{array}{l}\text { Digital subungual } \\
\text { keratoacanthoma }\end{array}$ & $\begin{array}{l}\text { Solitary, painful, rapidly growing, dome-shaped } \\
\text { endo-exophytic nodule with central horny plugs } \\
\text { filling the crater } \\
\text { Usually located beneath the distal free edge of } \\
\text { nail plate }\end{array}$ & $\begin{array}{l}\text { Epidermal hyperkeratosis, parakeratosis, central cra- } \\
\text { ter filled with amorphous keratin, dyskeratotic eosin- } \\
\text { ophils, patchy dermal lymphoplasmacytic infiltration }\end{array}$ \\
\hline $\begin{array}{l}\text { Recurring infantile } \\
\text { digital fibromatosis }\end{array}$ & $\begin{array}{l}\text { Multiple, smooth, round, firm erythematous } \\
\text { nodules on the dorsal aspect of the digits sparing } \\
\text { thumb and hallux } \\
\text { Infantile or childhood onset }\end{array}$ & $\begin{array}{l}\text { Myofibroblast-like cells with spindle-shaped nuclei in } \\
\text { dermis. These also stain for smooth muscle actin } \\
\text { Decreased elastic tissue }\end{array}$ \\
\hline Myxoid neurofibroma & $\begin{array}{l}\text { Solitary, flesh-colored nodule on the face, shoul- } \\
\text { ders, arms, feet, and periungual regions }\end{array}$ & $\begin{array}{l}\text { Spindle-shaped cells with wavy nuclei and mucin. } \\
\text { Positive for S-100 and negative for CD34 }\end{array}$ \\
\hline $\begin{array}{l}\text { Acral myxoinflammatory } \\
\text { fibroblastic sarcoma }\end{array}$ & $\begin{array}{l}\text { Painless, slow growing, ill-defined, multi-nodu- } \\
\text { lar lesions of size usually less than } 4 \mathrm{~cm}\end{array}$ & $\begin{array}{l}\text { Basophilic, hyalinized, myxoid tissue alternating with } \\
\text { lymphohistiocytic infiltrates and bizarre spindled or } \\
\text { vacuolated tumor cells (called pseudolipoblasts) } \\
\text { Emperipolesis and hemosiderin deposition }\end{array}$ \\
\hline $\begin{array}{l}\text { Koenen's tumor/ } \\
\text { periungual fibroma }\end{array}$ & $\begin{array}{l}\text { Multiple, firm, pinkish or skin-colored, conical } \\
\text { lesions emerging from under the proximal nail } \\
\text { fold } \\
\text { Seen in tuberous sclerosis complex }\end{array}$ & $\begin{array}{l}\text { Hypergranulosis, acanthosis, noncapsulated fibrosis } \\
\text { comprising of stellate-shaped fibroblasts with verti- } \\
\text { cally oriented collagen and increased vascularity }\end{array}$ \\
\hline Dermatofibroma & $\begin{array}{l}\text { Solitary, painless, slow growing, firm nodule in } \\
\text { the distal subungual area or lateral nail fold } \\
\text { No collar of raised skin }\end{array}$ & $\begin{array}{l}\text { Ill-defined reticular dermal nodule containing very } \\
\text { thick hypocellular hyalinized collagen bundles in a } \\
\text { haphazard array } \\
\text { Elastic fibers are scarce }\end{array}$ \\
\hline
\end{tabular}

\section{References}

1 Fetsch JF, Laskin WB, Miettinen M: Superficial acral fibromyxoma: a clinicopathologic and immunohistochemical analysis of 37 cases of a distinctive soft tissue tumor with a predilection for the fingers and toes. Hum Pathol 2001;32:704-714.

2 Sawaya, JL, Khachemoune A: Superficial acral fibromyxoma. Int J Dermatol 2015;54:499508.

3 Ramya, Nayak C, Tambe S: Superficial acral fibromyxoma. Indian J Dermatol 2016;61: 457-459.

4 Ashby-Richardson H, Rogers GS, Stadecker MJ: Superficial acral fibromyxoma: an over- view. Arch Pathol Lab Med 2011;135:10641066.

5 Raghupathi DS, Krishnamurthy J, Kakoti LM: Cytological diagnosis of superficial acral fibromyxoma: a case report. J Cytol 2015;32:39-41.

6 Tardio JC, Butron M, Martin-Fragueiro LM: Superficial acral fibromyxoma: report of four cases with CD10 expression and lipomatous component, two previously underrecognized features. Am J Dermatopathol 2008;30:431435.

7 Ponce-Olivera RM, Tirado-Sanchez A, Peniche-Castellanos A, Peniche-Rosado J, Mercadillo-Perez P: Myxoid neurofibroma: an unusual presentation. Indian J Dermatol 2008;53:35-36.

8 Chahdi H, Damiri A, Oukabli M, Albouzidi A, Bouabid S, Lazrek K: Acral myxoinflammatory fibroblastic sarcoma. Orthop Traumatol Surg Res 2010;96:597-599.

9 Lehmer LM, Ragsdale BD: Digital dermatofibromas - common lesion, uncommon location: a series of 26 cases and review of the literature. Dermatol Online J 2011;17:2.

10 Hollmann TJ, Bovee JVMG, Fletcher CDM: Digital fibromyxoma (superficial acral fibromyxoma): a detailed characterization of 124 cases. Am J Surg Pathol 2012;36:789-798. 